Article

\title{
Cui Bono? Assessing Community Engagement in San Francisco Community Benefit Agreements
}

\author{
Madeline Streiff Buitelaar \\ UC Hastings College of the Law, San Francisco, CA 94012, USA; madeline.streiff@gmail.com
}

Received: 17 January 2019; Accepted: 21 March 2019; Published: 26 March 2019

check for

updates

\begin{abstract}
A community benefit agreement (CBA) that provides tax breaks to a company often has provisions to help uplift the area where the business resides. A number of San Francisco companies, especially those in the technology sector, have received tax relief, a tangible benefit granted in exchange for operating in designated blighted areas, the details of which are delineated in publicly available CBAs. One CBA requirement for the tax break-community engagement-defies easy measurement. This paper assesses whether San Francisco companies were held accountable for fulfilling this unclear but core CBA requirement, namely, engagement with disenfranchised community members, an important part of their corporate social responsibility. To assess the community engagement stipulation of CBAs, this paper presents background on CBAs followed by interview data from two anonymous community liaisons who were formerly or are currently responsible for community engagement at companies that received the tax break. Themes found in the interview data highlight the limitations of CBAs that result from the unequal social exchange between companies and the indigent residents of blighted areas where the businesses are located. The study concludes that the benefits of the vague and unenforceable community engagement provision of CBAs do not justify the companies' payroll tax exclusion. The disproportionality of this quid pro quo risks aggravating impoverished residents' resentment of companies and their employees. The relevance of this study's low participation rate among community liaisons is also discussed.
\end{abstract}

Keywords: community benefit agreements; Twitter tax break; community engagement; San Francisco; technology; payroll tax exclusion; gentrification; Tenderloin; corporate social responsibility

\section{Introduction}

Simultaneous with its technology boom, San Francisco, California (USA), has experienced a crisis in which new wealth has deepened socioeconomic divisions [1,2]. Numerous influential companies in San Francisco that are located in depressed areas have received tax breaks in exchange for helping the surrounding communities, an endeavor that is in line with corporate social responsibility (CSR) [3]. This type of arrangement can be controversial, such as when Amazon reneged on a decision to establish a corporate campus in Queens, New York. In this high-profile case, concerns emerged about how this move might aggravate gentrification by giving the company a disproportionate tax incentive compared with the benefits that the community would receive in exchange [4].

San Francisco has an acute need to reverse the effects of gentrification given the "unfettered capitalism operating at warp speed" that aggravates the gap between "those that have caught the technological wave and those that have been left behind" [5] (p. 17). This "technological wave" is expected to only grow, especially in the wake of the wealth gained from stock options as companies mature [6]. In particular, San Francisco has been singled out for its hyper-gentrification [7,8], resulting in notoriety that is in part due to the clash between the interests of high valuation "unicorns" and the political economy of urban development [9]. San Francisco's trajectory, considered by some as an "assault on the poor" [5] (p. 14), has prompted attempts to revitalize depressed urban areas. 
These ventures include partnerships with technology companies in which financial incentives are offered as a quid pro quo for a company's efforts to improve the quality of life of those living in areas where these companies operate. In the case of San Francisco's Central Market Street and Tenderloin Area Payroll Expense Tax Exclusion (in effect from 2011 to 2019), the partnerships also aimed to assuage tech employees' safety concerns [10] and align with business owners' worries about the "concentrated presence of the homeless population and the open use of drugs in the Tenderloin [that] hurt the business climate" [11] (p. 16).

These types of partnerships usually include formalized stipulations that delineate CSR policies, arrangements called community benefit agreements (CBAs). CBAs first emerged in the 1990s to mitigate the potentially negative impact of business expansion in areas where such development might "displace local residents and local businesses, either physically or through gentrification ... cause traffic problems and generate noise, pollution, or other nuisances ... [and] create jobs that pay a living wage and offer decent benefits for residents in the neighborhood or in a larger geographic community" [12] (p. 292). Over time, however, CBAs were generally created de novo and thus have steep implementation learning curves, as well as weak oversight of the long-term benefits promised to residents [13]. In addition, assessing how companies implement their CSR is complicated by confusion about what constitutes such "responsibility", to whom it is owed, and how to measure it in a valid manner. Anecdotal reports of individuals whose lives were transformed by corporate philanthropy [14] outnumber the rigorous studies that assess any large-scale impact of CSR [15], a deficit that also applies to CBAs [16], including those implemented in blighted areas of San Francisco.

\section{Purpose}

This article examines whether select San Francisco companies, primarily those in the technology sector, were held accountable for community engagement with disadvantaged community members in the Central Market Street and Tenderloin areas as required by their CBAs. To assess the community engagement stipulation of CBAs, this paper presents background on CBAs that provides context for interview data from two anonymous community liaisons that were responsible for community engagement at companies receiving the CBA tax break. Given the lack of published observations reported by community liaisons, the data in this paper help address a gap in the knowledge about the de facto implementation of CBAs' community engagement provision and have implications for businesses that espouse social consciousness while simultaneously seeking concessions in return.

\section{The Emergence of CBAs}

The balance between corporate and community benefits in business ventures was notable in the case of the first full-fledged CBA in 2001. This CBA involved the construction of a sports and entertainment complex in Los Angeles that included the Staples Center, known as the home arena for the Los Angeles Lakers. The CBA emerged following the project's first phase as a result of developers' unrealized promises to improve the living conditions of neighborhood residents, including affordable housing [17]. Of note, the CBA also included provisions to evaluate the fulfillment of the agreement 5 and 10 years later, stipulating that a performance of less than $80 \%$ of the CBA's goals for two consecutive years would compel the developer to devise a corrective plan amenable to a community coalition located in the area under development [12]. These types of specific stipulations that could help ensure corporate accountability for CBAs (see, e.g., [18]) are not typical of San Francisco CBAs, a point of contention that is discussed later.

\section{Why CBAs Matter in Ensuring that Communities Benefit}

Without carefully crafted CBAs and compliance mechanisms, communities may lose the opportunity to receive benefits that could otherwise result from development or tax revenue. For example, after the completion of the \$214 million Georgia Sports Dome, a structure that was the biggest domed stadium worldwide when it was built in 1992, plans materialized for a new 
stadium within 20 years. Atlanta and the state of Georgia not only committed almost $\$ 600$ million of public financing for its construction (of what would be the new $\$ 1.6$ billion Mercedes-Benz Stadium), but they also promised an unknown and unclear sum to maintain and run the facility over a 30-year period [19]. Yet, despite this enormous financial investment, the agreement lacked an enforceable provision delineating "how the money [would] be spent, and whether any of the procurement, jobs, or revenue [would] benefit local residents", even though a CBA negotiation could have produced binding agreements [19] (p. 1795). Thus, a CBA could have served as an invaluable tool to ensure a positive impact on the surrounding communities, especially given the infusion of hundreds of millions of taxpayer dollars [20]. This case illustrates how CBAs offer a major opportunity to have benefits accrue to communities that can otherwise be lost without due diligence.

\section{San Francisco's CBAs}

San Francisco began to push for tech investment in the blighted mid-Market and Tenderloin areas beginning in 2011 when Twitter threatened to leave San Francisco to avoid the 1.5\% payroll tax (subsequently a tax on gross receipts) imposed only on those businesses operating within city limits [21]. To prevent its departure, Mayor Ed Lee successfully launched the CBA popularly known as the Twitter Tax Break (by amending Article 12-A of the San Francisco Business and Tax Regulations Code to add Section 906.3) [22]. Initially, in 2011, CBAs were granted to nine companies, including Twitter [23,24], that relocated to the designated area, despite protests that Lee was coddling the burgeoning tech companies [21].

Twitter was the anchor for the planned renaissance of the area that initially involved "at least 18 firms, including Zynga, Pinterest, One King's Lane, Yahoo, Uber, Salesforce, Zendesk, Square, and Dolby relocating to or expanding in the area" [24] (p. 477). By 2015, six companies, Microsoft, One Kings Lane, Spotify, Twitter, Zendesk, and Zoosk, entered into a CBA with the Office of the City Administrator [22] (see Twitter, 2014 [25], for an example of a CBA). The companies with CBAs in 2018 were Fitness SF Mid-Market, Lever, PAE Engineers, Spotify, and Zoosk [26]. For up to 6 years within an 8-year period, companies seeking tax relief were required to negotiate a legally binding CBA for each year that they wished to be exempted from city payroll taxes otherwise levied (with a planned sunset date of 20 May 2019) [27]. This allowed companies the dual benefit of receiving tax relief while also cutting costs in areas that were less expensive to operate in than South of Market (SOMA) or the Financial District (the FiDi).

The CBAs resulted in companies providing cash grants that amounted to nearly $\$ 3$ million from 2014 to 2016 (two-thirds of which was from Twitter alone, with its 1900 employees at its headquarters) to nonprofits in the blighted area. This sum was equaled by in-kind donations to these nonprofits. Community benefits also resulted from employees patronizing local establishments (e.g., restaurants), as well as from companies using neighborhood businesses to perform work such as cleaning [28,29]. In turn, the businesses benefited from payroll tax savings totaling \$1.9 million in 2012 and $\$ 4.2$ million in 2013 [30] (p. 19) [31].

\section{Oversight of Mid-Market/Tenderloin CBAs}

The Citizen's Advisory Committee (CAC) for the Central Mid-Market and Tenderloin Area, an 11-member committee appointed by the Board of Supervisors, helped devise and then engage in oversight of the CBAs to ensure that the signatories abided by the often-vague terms. The CAC was charged with meeting monthly with the community liaisons of the companies to learn about their progress and their compliance with the agreement, which focused on two broad goals: "stabiliz[ing] the surrounding at-risk communities" and promoting "ongoing engagement with the community" [32]. This engagement involved "a commitment to building relationships with the community's diverse stakeholders [because] [e]ncouraging employees to volunteer and to get to know the community where they work will also be beneficial to the company and its long-term success in a healthy and 
vibrant neighborhood" [33]. It is of note that this language about community relations highlights the company's increased chances of "long-term success", that is, a self-interested motivation.

These goals, however, allow the CAC to issue only recommendations for companies. It remains unclear whether efforts to achieve these goals are required, strongly suggested, or have the force of the law behind them to ensure compliance with the program. Furthermore, while the CAC is the gatekeeper and allegedly scrutinizes companies' programs, the final—and sole—arbiter of a company's efforts is the Office of the City of San Francisco Administrator.

However, because of the logistical difficulties of measuring success, the perpetuation of CBAs has relied on hopes and good intentions, an interpretation that is based on a report by the San Francisco Office of the Controller, Office of Economic Analysis: "Each of these agreements is unique and reflects an agreement between each company and the City Administrator, incorporating the feedback of a Citizen's Advisory Committee created for that purpose. While these agreements are designed to provide tangible benefits to the Area's residents, their variety makes them difficult to evaluate as a group. Accordingly, this report makes no attempt to quantify the value of the CBAs in monetary terms" [30] (p. 6). Thus, the aforementioned desire "to provide tangible benefits to the Area's residents", that is, the hope that the programs make a difference, apparently served as sufficient grounds to continue the program; uncertainty about the extent to which the agreements retain or attract businesses limits the ability to assess the fiscal impact (a problem also recognized in assessments of San Francisco's separate stock-based compensation payroll tax exclusion in which the identity of the companies benefiting is "confidential" [34] (p. 2).

The lack of data about financial implications and the inability to assess programs has seemingly resulted in the rubber stamping of CBA renewals. As a result, according to the Office of the City Administrator, "re-negotiation is the city's main means of enforcing the agreements. So far, no company has been denied a renewed exemption with a new community benefits agreement as a result of poor performance on the previous year's agreement" [28] (para. 14). While some companies decided against renewing their agreements following the first round of CBA approvals, the apparent lack of any consequences for non-compliance raises the question of what measurable outcomes would constitute "poor performance". It is also unclear whether any sanctions or publicity would result from a performance deemed subpar.

These issues indicate that CBAs benefit companies with very tangible payouts, while, at the same time, there is little evidence of any sort of rigorous standards for adherence to the terms in the agreements or even effecting visible change or improvement in the surrounding areas. Companies are able to opt in and out, yet, in contrast, the communities so greatly affected by the companies' presence have little agency to reclaim or shape their neighborhood.

The distrust that could result from the perception that companies implement CBAs at will and for opportunistic reasons is informed by social exchange theory. Mutual dependence brings people together, while unequal dependencies create imbalances in power that produce inequalities in exchange benefits such that the less-dependent actors are advantaged. These inequalities in exchange can result from the structure of power and dependence that is disconnected from actors' intentions or even awareness of their power relative to those with less influence.

Inequalities in exchange outcomes resulting from structures of imbalanced power exacerbate reactions to injustice by the disempowered while the more advantaged are more likely to view unequal exchanges as fair. Unilateral acts with mutual benefits (as opposed to strict, binding agreements that negotiate reciprocity) can reduce tension in how all actors in unequal power relations feel about each other by boosting solidarity: feelings of trust, affective regard, and fairness [35].

\section{Power Imbalances in San Francisco}

All of the negotiations involved in CBAs occur within a context in which there is a stark power imbalance that is driven by the juxtaposition of wealth and dystopic conditions. The extreme nature of the disparity between the privileged and the destitute has created a backlash against the tech 
industry $[5,36]$. The animus directed at tech companies is not just about the evolving identity of the city but also about the responsibility that certain companies bear in the expansion of the class divide:

There has been a sizeable political and cultural backlash against the impact of the technology sector on the city ... [such as] the private "Google bus" shuttles between San Francisco and the Valley which are accused of promoting gentrification and obstructing municipal buses; the role of Airbnb listings as a tool for landlords to evict low-wage renters in the city, and a backlash against ride-sharing services such as Uber from the taxi lobby [9] (p. 495).

This blowback complicates companies' attempts to present their community engagement as truly altruistic when it could appear to be a strategy to burnish their image and defuse tensions. Thus, valid assessments establishing whether CBAs accomplish their goals could help assuage these escalating tensions, starting with transparency about what works and what requires a fresh approach.

\section{Methods}

To understand more about the potential of CBAs to promote socially valuable outcomes, the author sought to interview community liaisons that were presently or previously responsible for managing CBAs at companies that had at any point participated in the 8-year long Central Market Street and Tenderloin Area Payroll Expense Tax Exclusion (in effect from 2011 to 2019). Interview questions were designed to gain information about companies' motivation for participating, their goals, how they measured success, what engagement meant, and the company-city power dynamic (that is, whether they saw the city as an authority in a more top-down structure or as a partner).

After the approval of this study by the IRB-accrediting Western Institutional Review Board, 10 potential participants that either currently or previously served as the community liaison for their company's CBA were identified. In March 2018, the author emailed a letter to these individuals that were listed as the contact person, that is, the community liaison, in the publicly filed CBA agreement. All 10 individuals emailed were the companies' designated contact person for members of the community, a position required by the CBAs. The letter informed participants of the confidentiality of their participation and identity-both as individuals and as company representatives (see Appendix A for the text of the email soliciting participation).

Only three community liaisons responded, and just two of them agreed to be interviewed. In April 2018, interviews were conducted in a private space in the respective offices of Companies A and B, scheduled at their convenience. Each interview lasted about $30 \mathrm{~min}$ and was recorded (with the permission of the interviewee) for subsequent transcription. The transcribed interview data were read thoroughly to identify salient themes and to place the findings within existing knowledge about community engagement as part of CSR. Because of the free-flowing, informal nature of the two interviews, the presentation of the data is structured such that related comments mentioned at different points in the conversation are reported in a way intended to facilitate readers' understanding of what constituted community engagement and whether the interviewees thought that these efforts were effective.

\section{Findings}

Of the two respondents obtained for this study, the first respondent, from Company A, responded to the email within a day and organized a time to meet and conduct the interview at the respective company. The liaison for the second company that responded, Company B, was no longer working at the office but connected the author with their replacement (an individual that was not listed on any public filings or documentation). The interview with the community liaison for Company $\mathrm{B}$ was conducted at their office. The third community liaison at a major tech company that responded to the email was willing to schedule three separate phone calls, yet they could never be reached at the arranged times. After numerous follow-up emails (over a period of months), this liaison 
stopped responding. As mentioned above, no other community liaisons ever responded, despite two subsequent email inquiries, sent a week apart.

\section{Company A's Approach to Fulfilling Its CBA}

When Company A explained their motive for participation, they stated that the obligations were in line with what they were already doing voluntarily and provided a reward "for what we are and what we do" rather than indicating that their community service was spurred by getting a tax break. Their community service initiatives primarily involved partnering with already-established philanthropic organizations, such as the Salvation Army, but not having their own employees engaged independently.

Their identity was allegedly as an entity that has "traditionally done a lot for the community" and that served as "a staple in the community". One statement was particularly telling: "We want to help the community and be recognized for it" - a clear indication that community engagement was an opportunity for branding. Yet, as the conversation progressed, the interviewee admitted that employees and visitors viewed the location of the business as "dangerous" and that "people were scared". The interviewee noted that the degraded environment, "directly affects our business".

While Company A felt very strongly that community engagement was part of their identity, the interviewee did not have a clear idea of what success meant or how to measure it. The interviewee admitted being a step removed from the services that their established, non-profit partners offered to the community. While the company purported to prioritize sharing their work with its intra-company customers and partners, there was little information on whether they receive feedback from the community stakeholders in the areas they seek to ameliorate, as there were two individuals that organized the CBA-related efforts-one that went to the meetings to deliver the reports to the CAC, and one that partnered with the philanthropic organizations-and there was a slight disconnect between the two.

When asked about how they received feedback for their work and whether they engaged with the community, the Company A interviewee replied, "We rely on the partners to let us know; we don't hear it directly." In order to assess whether they were reaching their goals, the interviewee discussed the conception of "this net that's getting bigger and that's how we can gauge the growth of who we're reaching, but that's really the only way we can gauge our growth a bit because our connections are becoming bigger and tighter." The interviewee was trying to convey that they measure their success by that of the organizations which they support, rather than measuring employee participation or financial contributions, etc. When asked whether they have a forum to receive feedback from the Tenderloin community, the interviewee claimed that the focus was not on the populations that they sought to help but rather on intra-company individuals, such as employees and patrons of the company's business. The interviewee was willing to admit that the community "really didn't know a lot about what we did, how much we did", and this contributed to a shift in marketing to focus on their purported identity as a locally owned and community-minded company to gain more customers, rather than focusing on fulfilling the alleged goal of community revitalization.

Company A minimized any concerns about compliance with the CBA and meeting obligations, noting that the process was "very structured" with "very set meetings" that involved specific directions stipulating "what you have to do". The interviewee did not seem concerned with fulfilling the terms of the CBA agreement as something particularly challenging or daunting and conveyed that it was a foregone conclusion that the city would consistently approve their efforts-it was reported as a formulaic process where approval was assumed. In particular, the interviewee referred to different amounts of donations they had to reach or a certain number of criteria they had to fulfill in order to get the break, but there was no expressed concern about the general mandate of the goals in the company's CBA that deal with the welfare of the community.

The interviewee admitted that fulfillment of its CBA was not based on instilling the feel-good benefits of voluntarism that could result from having their own employees engaged in working with 
the community. Instead, their engagement, only through partners, was driven by dangers of the location that apparently frightened not only employees but also potential customers.

Despite the lack of bonding with the community that the CBA attempted to encourage, community engagement was purportedly important, even while the interviewee was unable to articulate what success would entail or how to measure it. The focus was clearly on supporting the organizations that reached out to the community, creating distance between the company and what their established, non-profit partners offered to the community.

Thus, fulfillment of the CBA was based on the partnership rather than on what the partners accomplished according to either the partners' reports of their work or reports about the partners from the community itself. The interviewee's limited awareness of the impact was in part attributed to having two different people fulfill the CBA (one that attended meetings to deliver the reports to the CAC and another that liaised with the philanthropic organizations), as well as the lack of clear and regular communication between these two persons.

There was a reliance on waiting for feedback to filter back rather than making efforts to learn from the organizations (or target population) as to how they might be benefiting from companies' CBA-related efforts. Success was presumed by the reach of their partner organizations or an amorphous net of connectivity rather than such factors as employee participation or their financial contributions.

Perhaps because of this disconnect between the company and the community served, the interviewee touted the fact that the company is a locally owned, community-minded business. Finally, the pro forma CBA approval and compliance process seemed to justify documentation of the process rather than results (concrete contributions to community revitalization or community engagement by employees).

\section{Company B's Approach to Fulfilling Its CBA}

At the start of the interview, the Company B interviewee homed in on their mission as the CBA liaison: "We have to make sure that there's not displacement of people that live in the neighborhood, that you're trying to mitigate the effects that gentrification can cause. So Citizens Advisory is there to make sure that we are actually serving those and benefiting those that live in the Tenderloin."

The interviewee also noted the importance of engagement for the company's employees. When asked about the benefits of participation, the community liaison opined that involvement, "opens their eyes, rather than just saying the TL [Tenderloin] is just this gritty place-which it is—but there's this deeper part of it. It also has the highest population of children than any other neighborhood in San Francisco. It's multidimensional. It's not just immigrants; it's people that have lived here, San Franciscans, for 50 years. It's a mix of people so it really opens their eyes to the needs of the community and how we can work together to bridge that divide. The people that live here don't like techies-and the people that work here think: 'Ew, this neighborhood is gross.' How do you bring us together, not to have such a divide between the two factions?"

The Company B interviewee asserted that the agreement was largely for companies, stating, "This legislation was put in place to benefit the companies and did not give power on the other side to actually track how we're giving back to the community so it's kind of focused on companies and benefiting the company and not necessarily as focused on what effects it is having on the community as a whole." When asked about how rigorous the compliance mechanisms were for abiding by the terms of the agreements, the interviewee replied, "There are no real teeth to the [Citizen's Advisory] committee. They can advise, they can ask for revisions, but at the end of the day, it's really up to the City to approve these agreements, and according to the policy aide, they're never really turned down."

The interviewee for Company B was very direct in admitting that the locals did not like "techies" and, in turn, that the employees of Company B were repulsed by the neighborhood, implying that the reaction extended to the denizens of the neighborhood (who perhaps were seen as responsible for the blighted conditions of the area that the employees traversed daily). 
The interviewee was also very candid in conceding the existence of a power imbalance inherent in CBAs. This derived from a lack of accountability given the failure to either "track" the extent of "giving back" to the community or its impact. Furthermore, the interviewee viewed the disempowerment of the community as a conscious strategy by plainly stating that CBAs were "put in place to benefit companies", revealing the perspective that CBAs were primarily a vehicle to benefit businesses, not community members. This skepticism about the real intent of CBAs may have been driven by the interviewee's impression that the Office of the City Administrator grants carte blanche to the companies in devising, implementing, and assessing CBAs.

The interviewee expressed their sense that the 11-member Citizen's Advisory Committee (CAC) is ineffective in advocating for the interests of the community, either because of a lack of will to do so or because they are powerless to do so (given that their role is limited to advising the Office of the City Administrator). The interviewee emphasized their view that this modus operandi in which the CAC could only make recommendations disempowered not only the impoverished residents but also limited the power of the CAC to act on these residents' behalf to counterbalance the interests of the companies benefiting from tax breaks.

\section{Discussion}

The two interviewees had very different conceptions of the agreement, their obligations, and the enforcement oversight by the Office of the San Francisco City Administrator. Company A seemed to view its CBA responsibilities as a requirement rather than considering it within a broader context of community betterment: the role of community liaison was a mandated aspect of the CBA that also allowed the company to enhance its image, marketing, and internal identity. Company B espoused the importance of engaging with the community but recognized the challenges in achieving this goal logistically given the social class chasm and weak enforcement mechanisms.

The interview data on CBAs' community engagement provision illustrate its severe limitations, such as Company A's admission that their community engagement was in line with what they were already doing. In fact, the impetus for the energy spent on the CBA was the recognition they would receive, an unambiguous attempt to use the agreement for positive publicity and branding.

Despite Company B espousing the altruistic intentions of CBAs, an unequivocal admission of a seemingly insurmountable obstacle to fulfilling the goal was revealed when the interviewee mentioned employees' disgust at the "gross" neighborhood and denizens' dislike of opportunistic "techies". The interviewee's rhetorical question summed up the state of CBAs: "How do you bring us together, not to have such a divide between the two factions?" The sadness, resignation, and hopelessness of this statement that the author noted was corroboration of the gulf that exists between the good intentions of CBAs and their ability to make an appreciable and lasting difference that addresses social structural inequality.

One of the most telling disclosures of the Company A community liaison was the interviewee's focus on performing the bare minimum to comply with the CBA that enabled the company to receive the tax break. In the absence of any enforcement provisions, such as a timeline or consequences for failure to fulfill its promises (as described in the aforementioned CBA for the sports and entertainment complex in Los Angeles that included the Staples Center [12]), there was no indication that the Company A liaison thought deeply about enforcement or had any concerns about the consequences of falling short of what they were supposed to do to fulfill the mandate of the CBAs. Furthermore, the underlying driving force behind CBAs, improvement of blighted areas as part of a quid pro quo, was seemingly lost in the focus on compliance. By taking any pride in or credit for the efforts of another organization that largely receives support from elsewhere, a CBA becomes more lip service to community betterment, with a greater focus on how the company can boost its image by being part of something bigger and as a means to develop a distinguishing characteristic that could be seen as a competitive edge-especially in San Francisco, where many individuals tend to favor a local business 
over a large conglomerate. In addition, the liaison recognized that improving the Tenderloin also could help their business.

Despite the recognition of these advantages of CBAs, the agreement did not seem to motivate the liaison to orchestrate more direct involvement. Instead, engagement constituted letting members within the company know about related efforts rather than promoting greater involvement with the community. In other words, Company A's primary manner of involvement was based on their partnership with other organizations that were helping the Tenderloin; they then relied on those organizations to assess the community's needs and filter back information rather than pushing for company employees to have any direct contact. This partnership, in which other organizations actually implemented efforts to improve the community, resulted in support for existing non-profits via a financial contribution of an undisclosed amount, but not via working with or in the community in a way that could even approximate the "meaningful engagement" with the community cited as a central goal of CBAs. With the system permitting companies to focus on compliance over results, bureaucratic ritualism risks undermining the company's motivation to mitigate the effects of gentrification and income inequality. This then drives an unequal quid pro quo that may decrease residents' trust of both companies' short-term efforts and the government's priorities.

Consistent with social exchange theory, the disproportionate power of companies receiving large tax breaks ostensibly for the sake of the community can undermine solidarity. Despite the optics of an 11-member CAC advisory board, its lack of clout could grant too much power to the Office of the City Administrator such that the welfare of residents is at serious risk of being secondary to the interests of powerful companies. As a result, tension between company employees and local residents may persist so long as the community benefits are not commensurate with tax benefits.

\subsection{Demographic Factors Exacerbating the Divide}

Characteristics of tech workers, who tend to be young (late 20s) [37], complicate the social exchange imbalance. The workers have been called "digital gold miners" (see Tatsuno [38] for a discussion of this phenomenon), which is a term that refers to tech employees' alleged interest in upward mobility in the fast-moving tech world [39]. If Tatsuno [38] is correct, the population of tech workers is primarily focused on launching their careers and less interested in the uplift of the community in which they are working, especially considering their propensity to change jobs frequently, which may result in less commitment to the community in which they are working for only a relatively limited period of time. In fact, technology jobs have the highest turnover rate, with an average tenure of 2-3 years for most of the Bay Area-based tech companies, raising questions about employee loyalty to these companies [40].

\subsection{Entrenched Social Problems}

Aside from issues surrounding job mobility, manifold other problems contribute to the intransigence of community blight that defy a quick fix, especially homelessness, drug addiction, and mental illness. The mentally ill inhabiting the area [41] require the expertise of trained professionals; [41] even police who are called to deal with troubled residents find this population to be especially challenging and fraught [42-44]. The move toward the deprivation of liberty of the mentally ill reveals the intractable nature of these problems and speaks to the extremity of the hurdles found in blighted communities.

Among a population of about 44,000 people (about $5 \%$ of the city's population) in the Tenderloin, also called the Downtown Civic Center, about $10 \%$ are unsheltered homeless people who are living in an area in which social ills, such as open defecation and urination as well as discarded needles, are tolerated in this somewhat circumscribed area (according to [45]). In August 2018 alone, the Public Health Department's needle recovery program disposed of over 164,000 discarded needles [45]. Because of such profound problems, the Tenderloin has been deemed to be worse than slums in developing countries [46]. Thus, within these containment zones, the physical environment is often 
considered repulsive, likely impeding the building of community including some degree of esprit de corps between company workers and Tenderloin denizens, especially given that the community engagement ultimately serves to save the company money and to burnish its image. Furthermore, since companies' and employees' conceptions of the community may not be dependent on their offices' location, the notion that they could connect with residents of the Tenderloin could be unrealistic.

These factors underlying the fragility of relationships between companies and residents in blighted areas became evident in November 2018 when Spotify dropped its CBA and moved away from the mid-Market area (where it had been since 2013); the company relocated to the more prosperous Financial District of San Francisco. Employees interviewed anonymously by the media cited safety concerns, fears that likely contributed to the company's low number of CBA-linked annual employee volunteer hours-12.5-donated between January and November 2018 [23]. While it is unclear how residents perceived this rejection of the neighborhood, it nevertheless demonstrates that the laudable goals of CBAs are difficult to attain.

\section{Recommendations}

It is understandable that there would be flexibility in how CBAs are carried out, yet concomitant with such flexibility is the lack of any mechanism to gauge compliance. The interview data suggest that companies are aware of this loophole, as manifested either by putting in minimal effort (Company A) or by assigning responsibility to the city for approval and enforcement of CBAs (Company B), thereby operating under built-in rationales that could arguably minimize expectations for what is achieved under CBAs for companies that are, after all, profit-driven.

Returning to the question of how CBAs function without specific measures in place, the interview data indicate that CBAs should include specific and measurable goals with an enforcement provision. While it may be unappealing to rely on punishment to spur community engagement or other means to uplift a downtrodden community, there is precedent for rewarding altruism through individual donations with tax benefits and by allowing employees to use paid work hours to volunteer. This literature review, the results, and their analysis support the requirement for specific measurable goals that are monitored and enforced, with a clear mandate for corrective action to avoid penalties for companies that fall short.

In contrast to the sense of hopelessness about tech-community relations, an organization called the TechEquity Collaborative avows concern about the impact of the influx of tech companies in the Bay Area. Its website promises, "We are organizing the tech community to advocate for a tech-driven economy in the Bay Area that works for everyone. We believe the tech industry can and should generate widespread opportunity instead of inequality and displacement" [47]. On the other hand, it could be argued that the impetus for ensuring fair CBAs rests with the agency with enforcement power: the Office of the San Francisco City Administrator.

\section{Limitations}

Despite repeated attempts to contact community liaisons and the use of language designed to be compelling and non-confrontational, the author could secure only two interviews. In the case of four community liaisons that were contacted using the emails listed on the most current public CBAs, the emails all bounced back, with no way to deliver the message. Upon further investigation, no other information about the community liaisons was publicly accessible.

While difficulty securing respondents is a common research challenge, the author misjudged the likelihood that the community liaisons would fulfill their role of serving as the single point of contact to interface with members of the local community, which includes the author, whose law school is located in the Tenderloin (that is, the same general location of the companies contacted for this study). As persons charged with providing progress reports on the administration of CBAs, the study design was based on the expectation that the community liaisons, as part of their stipulated duties, would be both prepared and available to discuss the implementation of the community engagement provision of 
their CBAs. Notably, the email solicitation mentioned the author's interest in CSR (see Appendix A) so that community liaisons who were no longer responsible for CBAs (if the CBA had not been renewed by their company) could participate, regardless of which years or how many years their company had participated.

Despite these designated parameters of the community liaison role, some potential respondents may have felt that an honest appraisal of their work may have posed too much risk, with too little benefit, despite the confidentiality of the data to be reported anonymously, without any identifying information (including language that purposefully disguised the respondents' sex). Unfortunately, the study design did not permit the collection of anonymous interview data since in-person data collection meant that the author knew the identity of respondents; it is thus likely that potential respondents' apprehensions contributed to the low response rate. This factor may have been exacerbated by the limited number of companies with CBAs and thus the small pool of potential respondents (under 20), which, in turn, could have heightened fears about potential identification, despite assurances of confidentiality and anonymous reporting.

Finally, this study does not assess the companies' overall CBAs but rather their community engagement provision. As a result, the conclusions in this paper are not generalizable to overall philanthropic efforts or the CSR of the anonymous companies discussed or other businesses operating in the Mid-Market/Tenderloin area.

\section{Conclusions}

This study was conducted near the close of the 8-year period of the Central Market Street and Tenderloin Area Payroll Expense Tax Exclusion after companies had the opportunity to benefit from insights from prior methods employed by participants. However, this analysis uncovered no evidence that San Francisco companies had clear criteria for what constituted community engagement, a problem that complicates holding them accountable for fulfilling an effective CBA community engagement provision.

Because CBAs have rewarded companies with a tangible, measurable reward-money saved in taxes-a commensurate, measurable community benefit was warranted. The agreements entitled the companies to ascertainable savings in exchange for their commitment to engage with the surrounding blighted community, an undefined arrangement based on blind faith in the benevolence of the participating companies in the absence of diligent oversight.

Although the CBAs are monitored by the Citizen's Advisory Committee (CAC), the Office of the City Administrator is entrusted with enforcing them, despite insufficient processes in place to measure their impact. Thus, the relationship in CBAs favors powerful corporate entities left to their own devices when major financial incentives are at stake. Given the patent power imbalance and the heightening of tensions predicted by social exchange theory, this paper calls for further examination of whether CBAs should be allowed to operate without clear, measurable goals or the enforcement of progress toward these goals. While it could be argued that any increase in community involvement is ipso facto worthwhile, analysts should take heed to protect the interests of disenfranchised populations that are generally neither aware of nor have the agency to protest the inner workings of agreements that lack transparency.

The temptation to curtail bureaucracy and rely on companies' sense of duty to fulfill their stipulated obligation should be considered in light of the findings that a substantial portion of companies receiving benefits from the CBAs had neither a current contact person nor any individual that would respond to inquiries from a community member. This finding is especially concerning given that outreach and community-building were promulgated as key goals of the agreements and because many companies, even those without CBAs, have persons charged with community outreach. The difficulties in even reaching the community liaison in many cases are certainly contrary to the community engagement that was both expected and required of these liaisons; this inaccessibility casts doubt on the sincerity of achieving the goal of improving and connecting with blighted communities. 
CBA community engagement provisions appear to have done little more than serve as a stated desire to connect the more affluent with the underclass, while companies, mindful of the optics, are permitted to claim de jure compliance in lieu of metrics with appropriate oversight. To even begin to address the social ills in these communities requires the enforcement of a transparent, measurable commitment in order to create enduring change.

Funding: This research received no external funding.

Acknowledgments: I would like to thank my mentor, Professor Jodi Short, for sparking my interest in corporate social responsibility and for her invaluable guidance on this paper. I am also grateful to the two interviewees for their time and candor.

Conflicts of Interest: The author declares no conflict of interest.

\section{Appendix A}

In the email solicitation, interviewees were told that the data would be reported anonymously, with no identifying characteristics or information to be reported that could link them to their responses.

"I am a third year law student at University of California, Hastings College of the Law. I am researching companies' corporate social responsibly programs in the Tenderloin.

My project seeks to learn more about how companies conceptualize and operationalize their local corporate social responsibility programs.

I would love to speak to you about your role as a community liaison. Neither your personal identity nor your company would be identifiable. Please let me know if I could meet you at your office or speak on the phone. The interview will take no more than $30 \mathrm{~min}$.

Thank you very much for your consideration."

\section{References}

1. Kemeny, T.; Osman, T. The Wider Impacts of High-Technology Employment: Evidence from US cities. Res. Policy 2018, 47, 1729-1740. [CrossRef]

2. Maki, S. New York Beats Out San Francisco to Be World's Best Tech City. Bloomberg.com. 4 February 2019. Available online: https://www.bloomberg.com/news/articles/2019-02-04/new-york-beats-out-sanfrancisco-to-be-world-s-best-tech-city (accessed on 14 March 2019).

3. Carroll, A.B. Corporate Social Responsibility: Evolution of a Definitional Construct. Bus. Soc. 1999, 38, 268-295. [CrossRef]

4. Goodman, J.D. Amazon's Retreat on New York City Headquarters Followed Unexpected Backlash. New York Times. 14 February 2019. Available online: https://www.nytimes.com/2019/02/14/nyregion/amazon-hq2queens.html (accessed on 10 March 2019).

5. Solnit, R.; Schwartzenberg, S. Hollow City: The Siege of San Francisco and the Crisis of American Urbanism; Verso: London, UK, 2000.

6. Redmond, T. Could SF Tax New IPO Wealth? 48hills. 13 March 2019. Available online: https:/ / 48hills.org/ 2019/03/could-sf-tax-new-ipo-wealth/ (accessed on 14 March 2019).

7. Metcalf, G. Sand Castles Before the Tide? Affordable Housing in Expensive Cities. J. Econ. Perspect. 2018, 32, 59-80. [CrossRef]

8. Opillard, F. Resisting the Politics of Displacement in the San Francisco Bay Area: Anti-Gentrification Activism in the Tech Boom 2.0. Eur. J. Am. Stud. 2015, 10. Available online: https://journals.openedition.org/ejas/ 11322 (accessed on 10 March 2019). [CrossRef]

9. McNeill, D. Governing a City of Unicorns: Technology Capital and the Urban Politics of San Francisco. Urban Geogr. 2016, 37, 494-513. [CrossRef]

10. Russell, M. With Workers on Edge, SF Tech Companies Offer Self-Defense Classes. San Francisco Chronicle. 27 January 2019. Available online: https:/ /www.sfchronicle.com/business/article/With-workers-on-edgeSF-tech-companies-are-13563235.php\#photo-16826613 (accessed on 14 February 2019). 
11. Atuesta, M.; de Dios Ponce de León, A.; Monroe, M.; Womack, R. Redevelopment in the Central Market and Tenderloin: Displacement Risks or New Opportunities for Nonprofits $\mathcal{E}$ Small Businesses? Report for the Tenderloin Neighborhood Development Corporation. 2014. Available online: http://karenchapple.com/ wp-content/uploads/2015/06/Redevelopment-in-the-Central-Market-and-Tenderloin.pdf (accessed on 1 February 2019).

12. Salkin, P.E.; Lavine, A. Understanding Community Benefits Agreements: Equitable Development, Social Justice and Other Considerations for Developers, Municipalities and Community Organizations. UCLA J. Environ. Law Policy 2008, 26, 291-331.

13. Wolf-Powers, L. Community Benefits Agreements and Local Government: A Review of Recent Evidence. J. Am. Plan. Assoc. 2010, 76, 141-159. [CrossRef]

14. Thomas, G. 'Mayor' of The Tenderloin: 18-Year Addict, Dealer Now Helping Troubled Neighborhood's Residents Turn Lives Around. NBC Bay Area News. 1 August 2017. Available online: https:/ / www.nbcbayarea.com/news/local/Mayor-Of-The-Tenderloin-18-Year-Addict-Dealer-

Now-Helping-Troubled-Neighborhoods-Residents-Turn-Lives-Around-438022703.html（accessed on 20 December 2018).

15. Wood, D.J. Measuring Corporate Social Performance: A Review. Int. J. Manag. Rev. 2010, 12, 50-84. [CrossRef]

16. Belongie, N.; Silverman, R.M. Model CBAs and Community Benefits Ordinances as Tools for Negotiating Equitable Development: Three Critical Cases. J. Community Pract. 2018, 26, 308-327. [CrossRef]

17. Beach, B.S. Strategies and Lessons from the Los Angeles Community Benefits Experience. J. Afford. Hous. Community Dev. Law 2007, 17, 77-112.

18. Gross, J. Community Benefits Agreements: Definitions, Values, and Legal Enforceability. J. Afford. Hous. Community Dev. Law 2007, 17, 35-58.

19. De Barbieri, E.W. Do Community Benefits Agreements Benefit Communities. Cardozo Law Rev. 2015, 37, 1773-1825. [CrossRef]

20. McClurg, D. Leveling the Playing Field: Publicly Financed Professional Sports Facilities. Wake For. Law Rev. 2018, 53, 233-264.

21. Steinmetz, K. What the Twitter Tax Break Means For San Francisco. Time. 28 February 2014. Available online: http:/ / time.com/14335/twitter-tax-break-san-francisco/ (accessed on 20 February 2019).

22. Office of the City Administrator. Successfully Signed and Renewed: The 2015 Community Benefit Agreements. 2015 Community Benefit Agreements (CBAs). Available online: https://sfgsa.org/2015community-benefit-agreements (accessed on 20 February 2019).

23. Li, R. Spotify Gives Up SF Mid-Market Office-And Tax Breaks-Amid Safety Concerns. San Francisco Chronicle. 7 December 2018. Available online: https:/ /www.sfchronicle.com/business/article/Spotify-givesup-SF-Mid-Market-office-and-tax-13450875.php (accessed on 8 December 2018).

24. Stehlin, J. The Post-Industrial 'Shop Floor': Emerging Forms of Gentrification in San Francisco's Innovation Economy. Antipode 2016, 48, 474-493. [CrossRef]

25. Twitter. Community Benefit Agreement 2014 Renewal, Memorandum of Understanding. (CCSF Business \& Tax Regulations Code statute906.3(c)(5). Office of the City Administrator. 2014. Available online: https://sfgsa.org/sites/default/files/FileCenter/Documents/11484-TwitterCBA.pdf (accessed on 20 February 2018).

26. Office of the City Administrator. Community Benefit Agreements 2018. Available online: https://sfgov.org/ centralmarketcac/community-benefit-agreements-2018 (accessed on 16 February 2019).

27. OEWD. San Francisco Office of Economic and Workforce Development. Central Market Street and Tenderloin Area Tax Exclusion Map. 2019. Available online: https://oewd.org/sites/default/files/FileCenter/ Documents/235-CMTPTE\%20Boundary\%20Map.pdf (accessed on 16 February 2019).

28. Abello, O.P.S.F. Tax Break Tapped by Twitter Is Intended to Help Struggling Neighborhoods. Next City. 31 May 2017. Available online: https://nextcity.org/daily/entry/san-francisco-tax-breaks-twittercommunity-benefits-agreement (accessed on 15 December 2018).

29. OEWD. San Francisco Office of Economic and Workforce Development. Central Market Street and Tenderloin Area Payroll Expense Tax Exclusion. 2019. Available online: https:/ / oewd.org/central-market-street-andtenderloin-area-payroll-expense-tax-exclusion (accessed on 16 February 2019). 
30. Office of the Controller, Office of Economic Analysis. Review of the Impact of the Central Market Payroll Tax Exclusion. 27 October 2014. Available online: https:/ / sfcontroller.org/sites/default/files/FileCenter/ Documents/5914-CMPTE\%203\%20year\%20review_final.pdf (accessed on 17 February 2019).

31. Office of the Treasurer \& Tax Collector, City and County of San Francisco. Annual Report to the Board of Supervisors. Tax Collector's Annual Report: Central Market \& Tenderloin Area Payroll Expenses Tax Exclusion. 1 September 2016. Available online: https:/ / sftreasurer.org/sites/default/files/2015\%20Reports. pdf (accessed on 17 February 2019).

32. Central Market Citizens Advisory Committee. Framework for Community Benefits Agreements. 21 June 2012. Available online: https:/ / sfgov.org/centralmarketcac/sites/default/files/FileCenter/Documents/ 8937-Central\%20Market\%20CAC\%20-\%20CBA\%20Framework\%20Revised\%20Draft\%20\%286-21-12\%29. pdf (accessed on 17 February 2019).

33. CBA Framework. Framework for Community Benefit Agreements, Central Market Citizen's Advisory Committee. 21 June 2012. Available online: https://sfgov.org/centralmarketcac/sites/default/files/ FileCenter / Documents / 10356-2012\%20-\%20CAC\%20Central\%20Market\%20-\%20CBA\%20Framework\% 206-21-12.pdf (accessed on 16 February 2019).

34. Controller. Stock-based Compensation Payroll Expense Tax Exclusion. Office of the Controller. 4 February 2019. Available online: https:/ / sfcontroller.org/sites/default/files/Documents/Economic\%20Analysis/ Stock-Based\%20Compensation\%20report.final_.pdf (accessed on 14 March 2019).

35. Fiske, S.T.; Molm, L.D. Bridging inequality from both sides now. Soc. Psychol. Q. 2010, 73, 341-346. [CrossRef] [PubMed]

36. Fuller, T.; Stevens, M. California Today: Readers Weigh In on the Dirtiest Block in San Francisco. New York Times. 9 October 2018. Available online: https://www.nytimes.com/2018/10/09/us/sanfrancisco-homeless-crisis.html (accessed on 17 February 2019).

37. Pelisson, A.; Hartmans, A. The Average Age of Employees at All the Top Tech Companies, in One Chart. Business Insider. 11 September 2017. Available online: https://www.businessinsider.com/median-techemployee-age-chart-2017-8 (accessed on 17 February 2019).

38. Tatsuno, S. San Francisco Renaissance: Yet Another Gold Rush. In Entrepreneurial Renaissance: Innovation, Technology, and Knowledge Management; Springer: Cham, Switzerland, 2017; pp. 143-152.

39. Luckerson, V. How Election Day Turned Homelessness in San Francisco Into a Referendum on Big Tech. The Ringer. 7 November 2018. Available online: https:/ / www.theringer.com/tech/2018/11/7/18072556/ san-francisco-homelessness-proposition-c-vote-marc-benioff (accessed on 17 February 2019).

40. Fagan, K. Silicon Valley Techies Get Free Food and Dazzling Offices, But They're Not Very Loyal-Here's How Long the Average Employee Stays at the Biggest Tech Companies. Business Insider.com. 16 April 2018. Available online: https:/ / www.businessinsider.com/average-employee-tenure-retention-at-top-techcompanies-2018-4 (accessed on 17 February 2019).

41. Smith, S.C. Development Economics Meets the Challenges of Lagging US Areas. Hamilton Project.org. Brookings Institute. September 2018. Available online: http:/ / www.hamiltonproject.org/assets / files / PBP_ Smith_web_0927.pdf (accessed on 20 February 2019).

42. De Tribolet-Hardy, F.; Kesic, D.; Michael Thomas, S.D. Police Management of Mental Health Crisis Situations in the Community: Status Quo, Current Gaps and Future Directions. Polic. Soc. 2015, 25, 294-307. [CrossRef]

43. Haigh, C.B.; Kringen, A.L.; Kringen, J.A. Mental Illness Stigma: Limitations of Crisis Intervention Team Training. Crim. Justice Policy Rev. 2018. [CrossRef]

44. Rossler, M.T.; Terrill, W. Mental Illness, Police Use of Force, and Citizen Injury. Police Q. 2017, 20, $189-212$. [CrossRef]

45. Fuller, T. Life on the Dirtiest Block in San Francisco. New York Times. 8 October 2018. Available online: https:/ / www.nytimes.com/2018/10/08/us/san-francisco-dirtiest-street-london-breed.html (accessed on 25 February 2018). 
46. Brinklow, A. Some SF Streets Filthier Than World's Poorest Slums, Says UC Berkeley Professor. SF.curbed.com. 19 February 2018. Available online: https:/ / sf.curbed.com/2018/2/19/17029308/trash-needles-feces-sanfrancisco-streets-dirty-hazard (accessed on 25 February 2018).

47. TechEquity. Available online: https://techequitycollaborative.org/about/ (accessed on 16 February 2019).

(C) 2019 by the author. Licensee MDPI, Basel, Switzerland. This article is an open access article distributed under the terms and conditions of the Creative Commons Attribution (CC BY) license (http:/ / creativecommons.org/licenses/by/4.0/). 